Historic, Archive Document

Do not assume content reflects current scientific knowledge, policies, or practices. 



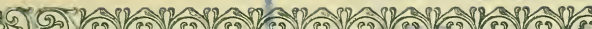

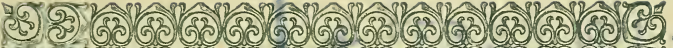

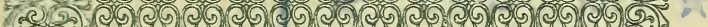
(5) (c) 250 (5) (C) (3) (ब) (ल) (क) (9) (5)( 7.(.) (क) (a) (3) (ब) (a) (स) $(30)$ (2) (-5) (2) स्टि( त्ञ) (3) (2) (ख) (ब) (य) क्षित (is) $\left(\mathrm{s}^{2}\right.$ (ㄷ) (5) (ल्ट) (ग) 군 (क) आ(3) (5) (a) (a) (다요 (D) (5) (5) (ख) (a) $1(5)$ (5) (N) (a) (2) (ल) (ए) 78 (ए) (ब5) (2). (2) (5) (ल) (य) (5) (5) a) (c) $(2)$ (ल) (ब) (ल) 70 (5) (1) (a) (I) (ब) (9) (क) (र) (C) (9) (5)(0) (ल) (ब) (5) 5 ब. का स्ड त)

C०का? PRICE LIST SPRING 1921

1266 WASHINGTON AVE. OGDEN, UTAH

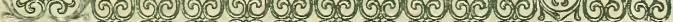

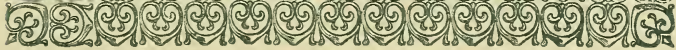




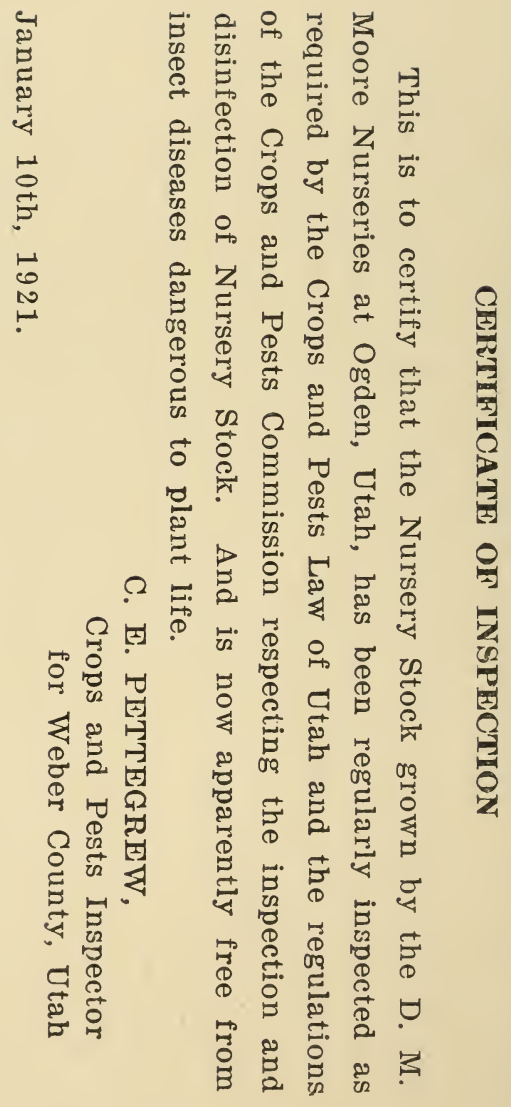




\section{HINTS ON PLANTING}

First-Be sure that roots of trees and plants are kept moist and well covered from time of leaving nursery until planted.

Second-Dig holes larger and deeper than necessary to receive roots in their natural position without bending. Place tree in center of hole and fill with fine top soil, working same well among roots. When about two-thirds filled with soil, fill hole with water and when water has settled finish filling with soil; firm soil gently with the foot and rake surface level.

Third-When through planting, if oneyear old trees, cut back to a uniform height of about thirty inches from the ground. Side limbs should be cut close to rodv of tree. Peach trees should have side limbs cut to within one inch of body of tree. If two-year-old trees, there will be from three to six branches. Cut out all but three or four limbs suitable to form a well balanced top, and cut each side limb back to four or five inches from body of tree, leaving leader or center limb twenty to thirty inches long.

Fourth-If weather is warm and dry water thoroughly every six or eight days. Soil should be stirred with a hoe, as soon as dry enough to work mellow, after each watering.

Fifth-If trees are dry and shriveled when received, bury in moist soil for five or six days. If frozen, do not open box or bale, but bury until frost is drawn out.

Sixth-Never allow manure to come in contact with roots of newly planted trees or shrubs, but if put on top of ground after planting it is of benefit as a mulch.

Seventh-Never handle trees in frosty or windy weather. Set trees an inch or two deeper in soil than they stood in nursery. 


\section{TERMS AND CONDITIONS}

\section{READ CAREFULLY BEFORE ORDERING}

TERMS CASH-With order or before delivery. No reservation of stock will be made unless cash accompanies the order.

THIS LIST cancels all previous quotations and is subject to change without notice except on orders already booked.

ORDER EARLY - This may save disappointment. Never in the history of the business has there been such a widespread shortage in most all lines of nursery stock.

LOCAL DELIVERY - No charge for delivery to any part of the city on orders of $\$ 5.00$ or more, if cash accompanies order; otherwise a charge of 75 cents to $\$ 1.00$ for each delivery, according to distance. Delivery usually commences about March 15 th and continues to May 1st. 


\section{APPLE TREES}

Plant 30 to 40 feet each way.

Price: 65 cents each.

Yellow Transparent-Medium to large, pale waxen yellow; tree hardy.

Red Astrachan-Above medium in size; deep crimson, juicy, acid; a kitchen apple of best quality.

Banana-Tree vigorous, fruit medium to large, smooth and handsome; golden yellow with blush cheek.

Delicious-Large, ribbed and irregular; flesh sub-acid.

Jonathan-Medium size, skin yellow, nearly covered with dark red.

W. W. Pearmain-Medium, yellow, quality best; prolific.

Rome Beauty-Large, yellow and bright red. Flesh tender and juicy; tree a moderate grower.

Whitney (Crab) - Large, striped with red; tree very hardy. 


\section{PEAR TREES}

Plant 20 to 25 feet each way.

Price: 75 cents each.

Bartlett-The most popular of all pears; buttery and melting, with a rich, musky flavor. A young and constant bearer.

Kieffer-The Kieffer holds the position among pears that the Ben Davis does among apples. The tree is remarkably thrifty and healthy, and is seldom affected with blight.

\section{CHERRY TREES}

Plant 18 to 20 feet each way.

Price: $\$ 1.25$ each.

Montmorency-Red, productive, ten days later than Early Richmond.

Napoleon-Large, pale yellow, red cheek, firm.

Bing-Large, black, firm, juicy, sweet.

Lambert-Fruit large, mahogany colored, firm, sweet.

\section{APRICOT TREES}

Plant 18 to 20 feet each way.

Price: 75 cents each.

Jones-Medium, yellow, red cheek.

Moorpark-A favorite canning variety. 


\section{PLUM AND PRUNE TREES}

Plant 16 to 18 feet each way.

Price: 75 cents each.

Fellenburg Prume (Italian Prune. Large German Prune)-Medium to large; dark purple.

Satsuma-Medium, reddish brown, flesh dark red.

\section{PEACH TREES}

Named About in Their Order of Ripening.

Plant 16 to 18 feet each way.

Price: 60 cents each.

Mayflower-Large as the Alexander and a week or ten days earlier. Dark red; semicling.

Red Bird Cling-Semi-cling, red cheek.

Carman-Large; resembles Elberta in shape. Color, creamy white, red cheek.

Champion - Free-stone, creamy white, sweet, juicy.

Early Elberta-Fruit of good size, skin light orange with crimson cheek. Flesh firm and of fine texture.

Elberta-Large, yellow, with red cheek; flesh yellow, rather coarse and very firm.

Orange-Cling-stone; orange, round; of largest size. 


\section{GRAPES}

Plant 6 by 8 feet; 905 plants per acre.

Concord-Bunch and berry medium; fair quality, black. Vine vigorous, succeeds everywhere. 20 Cents each.

Black Pearl-Both fruit and vine would indicate this to be a cross between the American and foreign varieties. The vine, while not so hardy as Concord, is hardy enough to stand on trellis without winter protection. The fruit ripens early and is exceedingly sweet and meaty, equaling in quality the best foreign or California variety. 30 Cents each.

Muscat of Alexandria-Bunch large, berry large, oval, pale amber; flesh firm. Vine tender. 30 Cents each.

Thompson's Seedless-Small, yellow; firm, oval, seedless; prized for shipping and raisins. 30 Cents each. 


\section{GOOSEBERRIES}

Plant 6 feet each way; 1210 plants per acre.

Craghead (Poorman's, Brigham City, Etc.) -Bush strong and vigorous. Fruit medium to large, of best quality, color red. Perfectly free from mildew in some sections, affected more or less in others. 25 Cents each.

Columbus - Large, productive; color greenish yellow; good canning variety. 30 Cents each.

\section{CURRANTS}

Plant 5 feet each way; 1724 plants per acre.

Price: 25 cents each.

Perfection-Bright red, mild, plenty of pulp with few seeds. Less acid, of better quality and more prolific than any other large currant in cultivation. Should have rich soil.

Boskoop-A new black variety that excels all the older sorts in vigor of growth, productiveness and size of fruit. 


\section{RASPBERRIES}

Plant 2 by 6 feet; 3630 plants per acre.

Prices: $10 \mathrm{c}$ each; $50 \mathrm{c}$ per 10.

Marlboro-Beautiful bright scarlet; large, firm. Bush hardy and productive.

Dewberry or Trailing Blackberry-2 year plants.

\section{STRAWBERRIES}

Plant $1 \frac{1 / 2}{\text { by }} 3 \frac{1}{2}$ feet, 8712 plants per acre.

$$
\text { Price: } \$ 1.00 \text { per } 100 \text {. }
$$

Location and soil have so much to do with success that it is difficult to name any one variety that will do equally well in every place. Growers should test the different sorts and find which is best adapted to their soil before planting heavily of any variety. 


\section{GARDEN ROOTS}

Asparagus-French Giant. Dig trenches 12 to 14 inches deep and 2 to 5 feet apart. In these put 4 or 5 inches of well-rotted manure, and on this 3 to 4 inches of mellow soil. Lay roots in trench 14 to 16 inches apart, then fill trench with good rich soil, leaving roots 4 to 5 inches below the surface. Do not cut until the second year, and then only slightly. Price 5 cents each.

Rhubarb--Varieties, English and Van Dyke. For canning or cooking, quality unsurpassed. Rhubarb succeeds best in deep rich soil. The richer the better. Divided roots, 25 cents each. 


\section{SHADE AND ORNAMENTAL TREES}

Carolina Poplar-A very rapid growing tree with large, deep green leaves. Tree hardy.

3 years, 12 to 14 feet, $\$ 1.00$ each.

3 years, 10 to 12 -feet, 75 cents each.

Sycamore-A handsome tree with bright green leaves, often 8 to 10 inches in width.

3 years, 10 to 12 feet, $\$ 1.75$ each.

3 years, 8 to 10 feet, $\$ 1.25$ each

Box Elder-A tree of rapid, spreading growth. Valuable for producing a quick, dense shade. I have in stock trees that nave been budded from male trees. These trees will be of better form than the common Box Elder, and will not produce seed.

Budded trees, 1 year, 7 to 8 feet, 75 cents each.

Norway Maple-Of compact habit, broad, deep, green leaves. The most popular and the best of all the maples.

4 years, 10 to 12 feet, $\$ 1.75$ each.

4 years, 3 to 10 feet, $\$ 1.25$ each. 
Sycamore Maple - A vigorous, sturdy growing tree, large, deep green foliage, 4 years, 8 to 10 feet, $\$ 1.50$ each.

Silver Maple-Foliage bright green above and silvery underneath. 3 years, 10 to 12 feet, $\$ 1.50$.

English Walnut-6 to 8 feet, $\$ 1.25$ each.

Camperdown Elm-One of the finest lawn trees, branches having a uniform drooping habit, forming an umbrella-like head. Twoyear heads. Price, $\$ 2.50$ each.

Birch-Cut Leaved Weeping-Tall, slender, yet vigorous growth; graceful, drooping branches, silvery white bark and delicately cut foliage.

2 years, 5 to 6 feet, $\$ 1.50$ each. 


\section{EVERGREEN TREES}

Price, 3 to 4 feet $\$ 3.00$ to $\$ 5.00$ each.

For local delivery Evergreen trees, with the exception of pines, are taken up with a ball of soil on the roots, which is securely covered with burlap. In planting, dig a lole where tree is to stand, place tree in nole just as received from the nursery, cut the string that holds burlap in place, and, if soil is unbroken, lift tree gently and remove all burlap. If soil is broken and likely to fall away from the roots, do not attempt to remove the burlap, but lay it out smooth from the stem of the tree. Fill in carefully with fine, moist soil, which should be made firm enough by tramping to prevent roots being moved by the tree swaying in the wind.

Norway Spruce-A compact, symmetricalgrowing tree, the branches assuming a graceful drooping habit with age.

Colorado Blue Spruce-A native tree of the Rocky Mountains and one of the most beautiful of all evergreens. The foliage ranges from a rich silvery blue to dark green. Tree hardy and will succeed on a greater variety of soils than other evergreens. 


\section{ORNAMENTAL SHRUBS}

Snowball-An old shrub of large size, with large globular clusters of pure white flowers. 50 cents each.

Mock Orange-A rapid-growing shrub producing a mass of snow-white flowers similar to orange blossoms. 50 cents each.

Van Houttei-The grandest of all the spireas. When in flower is a complete fountain of white bloom, the foliage hardly showing. 50 cents each.

Lilac-Great improvement has been made in this well-known old favorite. Some of the newer kinds are very fine. $\$ 1.00$ each.

English Privet - When well trimmed, makes one of the most ornamental hedges. 6 cents each. 


\section{ROSES}

My roses are field grown on own roots. If tops should be broken or frozen to the ground, the plant is not lost, as new wood will spring from the roots and soon bloom again.

Prices, Assorted-2 years, 60 cents.

Madame Caroline Testout-Brilliant satiny-rose, deepening at center and bordered with silvery-rose.

Henriette, H. T.-One of the finest for bedding, garden and cut-flower purposes: blooms erect on long stems; buds long and pointed. Color fiery orange-crimson.

Edward Mawley-One of the finest of alı dark crimson Roses. A true perpetual fiow. ering Hybrid Tea.

Clara IVatson-Bright crimson, center tinted rosy peach, fine form and habit.

Gruss an Teplitz-Bright scarlet, shading to velvety crimson, superb.

Ia France-A most profuse bloomer; rose color, changing to silver pink; large and full with tea fragrance.

Kaiserin, A. V.-Creamy white, a strong, vigorous grower and constant bloomer. 


\section{HARDY CLIMBING ROSES}

Dorothy Perkins-Clear, shell pink; passing to deep rose; sweetly scented.

Silver Moon-Flowers very large. Pure white in color; petals of great substance, beautifully cupped, forming a clematis-like flower. The large bunch of yellow stamens in the center adds to its attractiveness.

Philadelphia Crimson Rambler - Deep, rich crimson, brighter and more intense than the old Crimson Rambler, with larger, fuller and more lasting flowers in panicles; extremely vigorous and productive, one of the hardiest, and entirely free from mildew.

Hiawatha-Glowing ruby-crimson, with a clear white eye; single flowers in clusters; light glossy green foliage; a seedling from Crimson Rambler; excellent for climbing, trailing or forcing.

American Pillar-Large single flowers of rich rosy-pink, approaching brilliant carmine, just a glint of white at center and golden-yellow stamens, a profusion of bloom almost covering the foliage. 


\section{HARDY PERENNIALS AND BULBS}

Mallow Marvel-The large flowers ( seven inches in diameter) appear early in August and continue without intermission until checked by frost. Colors: Crimson, white and pink. 30 cents each.

Alaska Daisy-The flowers are immense: pure white with yellow center. Plant not so tall as the Shasta, and does not need staking. 15 cents each.

Bleeding Hearts - Rose-colored, heartshaped flowers in drooping racmes. 30 cents each.

Paeonies-The most beautiful of all hardy perennial plants, rivaling the rose in perfection of bloom, coloring and fragrance. They are of the easiest culture and thrive in any soil, but give best results if planted in deep, rich, well drained loam. Plant two inches below the surface. 50 cents each.

1-Pure white, center petals occasionally flecked with red. Finest white paeony; fragrant.

8--A beautiful flower; guard petals deep pink, center buff.

7-Dark crimson, very double. 


\section{CLIMBING VINES}

Hall's Japan Honeysuckle-A vigorous, almost evergreen sort, with pure white flowers, changing to yellow. 40 cents each.

Clematis Paniculata-Of a rapid growth. Flowers are of medium size, fragrant, pure white and borne in tremendous sheets in September. Fine for trellis or porch. 50 cents each.

Clematis Jackmanni-Large, velvety, violet-purple; profuse bloomer. Strong twoyear-old plants, 75 cents each.

virginia Creeper-Has beautiful deep green leaves that change to crimson in autumn. 25 cents each.

Boston Ivy-A beautiful climbing vine. It clings firmly to walls, its overlapping foliage giving them the appearance of being shingled with deep green leaves. The plant is very slow and delicate at first, but gains in strength with age. 50 cents each.

Chinese Wisteria-A fine rapid growing climber; has long pendulous clusters of pale blue flowers. Bloom in May and June. 75 cents each. 
